\title{
Reading Deeply for Disciplinary Awareness and Political Judgment
}

\section{ABSTRACT}

What happens when students become better readers? Cultivating deep reading habits in students to help them navigate disciplinary cultures respects student autonomy. Scholarly literature predicts that three linked practices improve student reading: practice with feedback, explicit in-class work on reading strategies, and disciplinary norm discussions. To see what happens when students engage in these practices, I studied two years of students in an American Political Thought (APT) course, comparing essays written at the start and end of the courses. In this article, I analyze evidence of student learning by reading their work closely, and in the context of political theory as a humanistic sub-discipline, speaking both to "what is?" student reading and exploring its implications for citizenship through political theorist Hannah Arendt's reflective political judgment. As students deepen their reading practices, they are cultivating habits of citizenship, even if they still struggle with disciplinary awareness.

\section{KEYWORDS}

deep reading, judgment, disciplinary, humanities SoTL, metacognition

\section{INTRODUCTION}

I love reading political theory. I start my introductory class with thirty print-outs of Antigonean old, free translation - and pass them out like freshly baked cookies. My excitement is half-contagious, half-frightening, and students warily agree to read aloud the various parts. I want to share the experiences of digging for meaning, of inference, of finding the confusing and strange sentences and turning them into questions we mull over together. On this first day, reading goes well; the rest of the semester, it does not. Students come to class without mullable questions or, worse, without reading at all. Or they say, "I read this three times and still don't understand it." How can I share "the pleasures of difficulty" (Salvatori \& Donahue, 2004) so that students become joyous and dogged readers?

I want students to develop interpretive reading strategies appropriate for political theory and the humanities. This is made more difficult because political theory is a humanistic subfield within a social science, which means that even students who are sophisticated readers in political science often struggle to understand the expectations in a political theory class. Students may have developed sound strategies for interpreting contemporary texts that feature empirical data and descriptive claims, but political theory readings are old, abstract, and normative. The subfield puts unique demands on students who do not anticipate what one suspiciously called "a philosophy class in disguise," and another "one of those grey area classes.” They struggle with everything from Platonic dialogues to existential plays, not to mention medieval treatises and modern constitutions. This struggle is not, as I once thought, because they do not read the texts. Students may decode the words, but cannot always understand, much less analyze or enjoy, older or abstract texts. 
I want to understand what undergraduates experience when reading political theory texts, and also see what happens when they become better (sub)disciplinary readers. I draw on rich resources in the literature for improving reading comprehension, but also situate comprehension strategies in the disciplinary classroom. While I started off asking "what works?" (Hutchings, 2000, p. 4) to improve undergraduate reading in political theory, I shifted to "how does it work?" or "what is the larger cognitive process at work as student reading improves?" I collected student writing before and after using three deep reading practices in my course. Although my analysis concerns political theory, it can help instructors engage students with theoretical reading in many disciplines and consider their own disciplinary reading practices and strategies. Humanistic subfields in social science disciplines offer valuable opportunities for deep-reading because of their focus on textual evidence. I read the student essays as contributions to the field of political theory, and interpret them as such, using close reading to put them in dialogue with political thought. I discovered that students' deep reading improves, but they struggle with disciplinary metacognition. I interpret their gains as an intermediate step in developing what Hannah Arendt calls "political judgment" and use her theories to find meaning in the project.

\section{What does the literature tell us about reading and learning?}

Reading is an integral part of the learning process that we cannot assume students have mastered or will develop on their own; many enter unprepared for college reading (Gamel, 2015, p. xiv). Because students mostly read outside the classroom, we lack direct evidence of their ability and habits. Writing Across the Curriculum programs in which responsibility for teaching writing is shared beyond the composition classroom often insure that explicit writing strategies are addressed; there is no equivalent program for reading. Undergraduate students need powerful reading habits so they are not struggling alone in their dorm rooms or at their kitchen tables. Coercion does not produce deep engagement with texts (Hatteberg \& Steffy, 2013), nor are reading quizzes likely to require more than surface recall (Roberts \& Roberts, 2008). Intrinsic motivation to read is rare in university students who may have had traumatic experiences with reading in high school and before. Gamel (2015) differentiates between "resistive readers," who avoid reading, and "word callers," who say the words but lack comprehension. Both use strategies to get by, such as waiting until teachers answer their own questions. Achievement gaps connected to race and class inequality in the United States are visible in reading ability (Ross, Kena, Rathbun, KewalRamani, Zhang, Kristapovich, \& Manning, 2012; Reardon, 2013). Some students may also view reading in college as an instrumental act aimed at gaining a product - a college degree - to be shirked if possible (Schiefele, Schaffner, Möller, \& Wigfield, 2012). Some students may have little time due to work or family obligations, exacerbating any existing reading anxieties or lack of comprehension (Greene \& Maggs, 2015). Along with the lack of time, students may not always realize the benefits of reading, especially long-term benefits not tied to immediate outcomes like tests (Sharma, Van Hoof, \& Pursel, 2013).

Many reading research and literacy studies focuses on K-12 classrooms, where we assume students learn to read. However, this literature is still appropriate for undergraduates, who are still learning to select reading strategies and recognize disciplinary cultures. "Situated literacies" or "new literacy studies" explore reading practices "positioned in relation to the social institutions and power relations that sustain them" including but not limited to educational settings (Barton, Hamilton, \& Ivanič, 2000, p. 1). Goodman argued in the late 1960s that reading should not be understood as a process of decoding sequential words, but rather constructing meaning (Goodman, Flurkey, \& Xu, 2003). Reading is contextual, so Smith (1985) advocates for "Reading Without Nonsense," that is, resistance to a mechanistic and reductionist view of reading or learning. Smith (2014) argues that 
learning occurs effortlessly in the right conditions, focusing on the psycholinguistic development of children. While the broad themes of his work, such as the importance of feedback and attention to student responses, are applicable, work on language acquisition is less useful for helping college readers. That much work in literacy focuses on primary and secondary education makes sense, but can make finding resources for teaching college reading difficult. Gamel (2015) approaches this as an opportunity to infuse both remedial and college preparatory classes in high schools with research-based strategies that help students overcome difficulty and pursue inquiry. However, the focus on standardization emerging from the Common Core in secondary education sometimes limits the transferability of this work and may limit its effectiveness for all students; as Biesta (2007) argues, SoTL shows us "what worked" in a particular classroom, not what works everywhere.

In terms of work on higher education, it is light. Higher education researchers agree: "the number of college students experiencing difficulty with reading comprehension and study strategies is surprisingly high" (Martino \& Hoffman, 2002, p. 310). Still, many falsely hold "a belief that proficiencies automatically evolve as readers advance though school: that as long as students have acquired adequate basic reading skills, they will be able to read anything successfully," despite evidence to the contrary (Martino \& Hoffman, 2002, p. 4). Many publications on "college reading skills" are aimed at preparing high school students; although some of these strategies transfer to the college classroom, the most transferable teach reading and content together. Teachers increasingly teach disciplinary literacy so students think or read "like an historian" in history class or a scientist in a chemistry class (Wineburg, Martin, \& Monte-Sano, 2014). This approach also helps prepare students to read the non-fiction work common in college. This article considers disciplinary reading in specific university settings and reflects on them, building on and extending the research from the post-secondary classroom.

Post-secondary research often centers on these discipline-specific (yet transferable) deep reading practices that combine comprehension and criticality. The notion of "deep reading" captures the metacognitive nature of reading, where students reflect on their own process and reason about connections (Sperling, Howard, Staley, \& DuBois, 2004). Students consider their learning and monitor its progress, a way of thinking that may be essential for college success (Pintrich, 2002; Chevalier, Parrila, Ritchie, \& Deacon, 2015). Deep reading is "the array of sophisticated processes that propel comprehension and that include inferential and deductive reasoning, analogical skills, critical analysis, reflection, and insight" (Wolf \& Barzillai, 2009, p. 32). Deep reading, as defined by Bean, Chappell, and Gillam (2013), contrasts with surface or shallow reading and some digital literacies, and some digital humanists, like Hayles $(2010 ; 2012)$, explore and defend "distant" and other reading approaches. ${ }^{1}$ For Roberts and Roberts (2008), deep reading is "reading for long-term retention of material and for comprehension at a level that can be perspective-transforming," and requires going beyond a cost/benefit model (p. 125). Hermida (2009) argues we must make reading a university-wide responsibility: "if teachers explicitly teach students how to read academic texts in aligned courses where students have ample opportunities to engage in reading activities throughout the term, students are more likely to adopt a deep approach to reading" (p.20).

Deep reading is a broader cognitive process, rather than a technique like "speed reading" or "gutting." It requires linking texts to broader contexts and prior learning, applying or analyzing them, and reflecting metacognitively on this process. It connects metacognitive skills with reflections on meaning, purpose, and identity. While I will not be foregrounding debates about literacy, deep reading is associated with a constructivist understanding where reading and writing are part of a process where students co-create meaning in their learning and lives. Greene and Ackerman (1995) argue that constructivism, properly understood, entails an intertwined relationship between reading, writing, and 
learning in general, and foregrounds strategies and rhetorical constructions that help (or hinder) student learning. With deeper metacognitive reading as my goal, informed by the work in post-secondary reading theory, I was reasonably confident that student reading could improve. Yet I wondered what happened as reading improved. To study this process, I looked at the students' reading activities and responses during three new reading practices in two versions of American Political Thought (APT) in 2014 and 2015.

\section{Practice and feedback}

Practice helps, but it helps more if it is "goal-directed practice coupled with targeted feedback" (Ambrose, Bridges, DiPietro, Lovett, Norman, 2010, p. 125). This targeted feedback can come from instructor, peer, or self, and can be quick. Simple strategies like reflections, self-tests, or discussions where the text is used cultivate thoughtful reading practice. For example, I put up Antigone on the document camera as we read aloud, stopping to mark my curiosity or confusion. Modeling reading inquiry in class improves written work and use of textual evidence (Reznitskaya, Kuo, Clark, Miller, Jadallah, Anderson, \& Nguyen-Jahiel, 2009). Along with modelling reading, I support claims with textual evidence and require students to do the same. Students prepare for class by blogging about the reading, and in class we together examine posts that use textual evidence well or show critical engagement.

My students also approached their reading in relation to what they already knew and what they could easily find out, as in the classic "text to self, text to text, text to world" framework (Keene \& Zimmerman, 1997). Disciplinary insiders and deep readers situate their work in relation to the author, audience, and the historical and social context (Greene \& Ackerman, 1995). Starting the second week of class, students completed a framing assignment three times per semester. Before reading, they brainstormed everything they knew about the person, place, and time period of the text they were about to read, and then speculated about what they did not know. They also wrote notes on any parts in the text which reminded them of their own experiences or another class or idea. After they read the assigned text, they used these reflections in their usual blog post due before class. I reviewed their course blogs, and gave feedback that praised the use of context and prompted when lacking. This regular practice with feedback appeared in their blogs when they situated the reading in a disciplinary or broader context.

\section{Reflecting on reading together}

Along with strategies for reading at home, we read together in the classroom and discussed it as a classic "think-aloud." This step is often resisted by students and faculty who see reading as "homework;" however, discussing what we read together in the classroom is fruitful, especially if the alternative is reading without learning. Augmenting practice with explicit strategies and conversations is core to improving literacy, because this modeling helps promote metacognitive reflection (Pressley, 2000). Salvatori and Donahue (2004) and Gamel (2015) offer meditations and exercises to facilitate reading together. Students must talk about how they read as well as what (Strang \& Rogers, 1965). I begin the process by "cold" reading something I have never read in front of students, in a process that mirrors the writing that Thompson (2001) values for the way that instructors writing in front of the class "joined... students in the real risk of learning." ${ }^{2}$ With such work, reading practices are moved from private work and mark of individual intelligence towards a communal practice.

In my 2014 and 2015 classes, students monitored their reading strategies and habits through writing a reflective narrative about themselves as readers. For example, one student wrote about how their ${ }^{3}$ childhood joy in reading Harry Potter turned to dread because they could not read fast enough to complete their assignments and had to skim as much as possible. Then, about one-third through the 
semester, students shared these narratives in groups to learn about others' strategies and stories. Many contrasted loving childhood reading with struggling to keep up with assigned college reading. I also presented several formal approaches, such as concept-mapping, in-text mark-up, reflective questioning, and the note-taking strategy of SQ3R: survey, question, read, recite, and review. These strategies are most effective when rooted in a "question-finding" and reiterative process, rather than a rote or rereading focused approach (Mulcahy-Ernt \& Caverly, 2008). We brought examples of our use of these strategies to class and discussed what we learned from trying them together in small groups. To model the reflective and communal aspects of reading, I publically reconsidered how I read and why, and shared my reflections by placing a text on the document camera and showing how I might approach it better. We each chose a new reading strategy or resolution to use throughout the semester, with frequent check-ins. (The Harry Potter student decided to read one assignment per week slowly in full and accepted that they might not finish everything.)

\section{Disciplinary reading}

The above two strategies focus on creating habits through targeted feedback and communal reading practices, but they do not reach the problem of student reading in disciplinary and subdisciplinary contexts. When faculty approach a text in their field, they do so with their own reserve of expert knowledge not only about content, but also about format, evidence, and argument. fse et al. (2010) show how experts organize knowledge differently than new learners. Experts are on the other side of those pesky "threshold concepts," but in the process of crossing into deeper disciplinary expertise may develop "blind spots” about how non-experts might organize knowledge (Meyer \& Land, 2003). Disciplinary reading creates blind spots. Instructors regularly read disciplinarily in their working lives, following graduate education that trained them to read "like" a political scientist—or historian or chemist. To read like a student is hard. When I read Antigone or The Federalist Papers aloud on the first day class, exhilarated and sure that, once they have heard the passage, students will feel exhilarated too, I am confused when they do not. I need to re-learn un-disciplinary reading.

Instructors can start by modelling "disciplinary literacy" (Buehl, 2011; Monte-Sano, 2011; Shanahan \& Shanahan, 2008). This is a way to read with attention to a particular discipline or subdiscipline and its "signature pedagogies" (Gurung, Chick, \& Haynie, 2009; Chick, Haynie, \& Gurung, 2012) or ways of thinking that may need to be "decoded" (Middendorf \& Pace, 2004). We sometimes forget about reading when considering disciplinary awareness, even though we know experts read differently from novices (Shanahan, Shanahan, \& Misischia, 2011). As Moje, Young, Readence, and Moore (2000) note, although "many youth who have mastered the basic processes of reading and writing by the time they reach fourth grade, there is still much to learn about the practices associated with literacy, especially the ones unique to different disciplines, texts, and situations" (p. 401). This situation carries on into college, perhaps even more so, as we experts carry often unexpressed expectations about what good work looks like in our disciplines. Yet sharing these expectations exposes professors as gatekeepers to a way of thinking and speaking, and this power may be uncomfortable. However, discussing disciplinary lenses and approaches also helps students make choices about they want to study and understand the world. This choosing is a core practice of interdisciplinary learning, where students use multiple lenses. (Nist \& Holschuh, 2005).

Disciplinary reading initially privileges experts, but also produces blind spots for them that students can see. Because "literacy practices are patterned by social institutions and power relationships, and some literacies are more dominant, visible and influential than others," professorial literacies, in academia, dominate and hinder disciplinary reading that also values students' existing ways of knowing 
(Barton, Hamilton, \& Ivanič, 2000, p. 40). Students may be initially intimidated by disciplinary expert knowledge and norms, but also begin to recognize and critique them. Geisler (2013) claims the "only individuals with sufficient access to a discipline's domain content to make arguments are those who have already pledged their allegiance to the discipline's assumptions" ( $\mathrm{p}$. xvii). This privileging of expert "pledgers" places students in an awkward and disadvantaged midpoint between academia and the general public (Geisler, 2013). Yet it is this very midpoint that makes them attuned to instructor blind spots. Rather than seeing disciplinary norms as rules to be enforced, instructors can listen to students who are "citizen-experts ... conscious of the responsibility they have to readers, civic communities, and even themselves to produce accurate, reflective, and moral writing" (Sidler, 2005, pp. 49-50). Students spend time in many disciplines throughout their day and semester, leading to code switching that may allow them to see a discipline's limitations better than experts.

Sharing and problematizing disciplinary knowledge is particularly important when teaching in a strange corner of a discipline, such as political theory in political science or social theory in sociology. Students are often confused when these humanistic courses proceed differently from their social science courses. Instructors can help by presenting how their subfield bridges humanities and social sciences and how they see theory working in their discipline. They can revisit core debates about scope and methods from graduate school and share the intellectual history of the discipline and how theory relates to practice in their own work. Students gain disciplinary awareness by tracing the core debates in the field. ${ }^{4}$ While the weightiest debates may not be appropriate for an introductory class, something more the speed of Political Philosophy: A Very Short Introduction (Miller, 2003) helps undergraduates begin to see themselves as part of an ongoing dialogue about politics and how to study it. This approach will also help students recognize disciplines as sets of behaviors, codes, vocabularies, and methods. These are also opportunities to invite undergraduates into methodological conversations, treating them as colleagues rather than acolytes.

My students explored the differences between political theory and political science and activated their prior knowledge through mapping what they knew. In this third practice, students, first in groups and then class-wide, take an inventory of the classes they have taken and disciplines they have encountered and draw them out them in relation to each other. They wonder aloud how someone from each of these different disciplines might approach a specific problem. For American Political Thought (APT), we used the problem of homelessness. The first day, students created visual maps of how they think different disciplines might inquire about the problem, building their confidence in their existing rich web of disciplinary knowledge. On the second day, we read a political theorist and connected their approach to each student's map. We read Waldron (1991) on what homelessness tells us about liberal conceptions of property and freedom, and students placed Waldron's argument on their own maps, shared their maps with each other, and then built a class-wide map that connected their prior and current knowledge. Different classes will develop very different maps, some with focus on methods, some on subjects, and others even in relation to questions of publicness and utility. These maps give instructors insights about student reading and guide students to see new connections. At the end of the assignment, students generate a list of questions that constitute political theory's approach and keep a list of the questions they want to ask a text, whether they overlap with the discipline or not. In this way, students develop disciplinary reading ability and independent lines of inquiry.

\section{ANALYZING EVIDENCE OF STUDENT DISCPLINARY READING}

To analyze the results of these three practices, I conducted an IRB-approved study from 2014 to 2016 in my American Political Thought (APT) course, a 300-level offering that features mostly political 
science and Democracy and Justice Studies majors who are sophomores, juniors, and seniors. ${ }^{5}$ In this course, students read, interpret, and apply a variety of historical and theoretical texts about American political life, often to their frustration. In a recent anonymous course evaluation, a student argued that their low grade was unfair, "because I have a hard time finding underlying meanings in older texts." To improve their reading, I introduced the three practices above in the first two-thirds of the semester, with two weeks between each practice, devoting one class period ( 80 minutes) or the equivalent to each. Students wrote short essay responses before and after the course, interpreting short texts by Alexis de Tocqueville and Thomas Paine, which I use here as evidence of student learning. The second writing occurred after all three interventions, but before a shared reflective conversation about both this study and our reading practices to offer closure and consent to students.

It is hard to measure improved practices, especially reading practices, which involve many mental functions and do not lend themselves well to one-shot tests. Farr and Carey (1986) claim that "no one has devised a way to determine if what is read is put to use" (p. 39). Indeed, it seems that most teachers test recall from reading, rather than higher order skills (Allington, 2011). A student who scores well on a verbal exam, even the GRE, may not be able to actually use their reading. While recognizing the limitations of measuring reading, I still wanted to know how students read, so I inferred from their short essay responses, comparing those written before we began the three evidence-based practices and those after. $^{6}$

I used a version of Bloom's Revised Taxonomy to examine students' deep reading processes, building on previous adaptations for SoTL work (Veeravagu, Muthusamy, Marimuthu, \& Michael, 2010). The two short essays, pre- and post-course, included open-ended questions so students could show what they could say about the reading, using question stems devised from the Taxonomy (Krathwohl, 2002). In both tests, students answered five questions, corresponding to Bloom's levels of thinking, about each piece of writing. For the texts themselves, I choose pieces that were commonly assigned in such a course: excerpts from Thomas Paine's ([1792] 2003) Common Sense and Alexis de Tocqueville's Democracy in America (2000). Both pieces are of similar difficulty and concern liberty and equality, key themes in the course. Students had a week to read the piece and received a Pass/Fail grade for completing the assignment, but I analyzed their writing after the semester ended. For the purposes of this article, I focus on the answers related to Bloom's higher order levels: analyze, evaluate, create. While the lower levels—remember, understand, and apply_are also important, they are less linked to deep reading, and student performance on them did not change significantly.

In analyzing student work, I also explore how political theorists might approach SoTL. Political theorists rarely use quantitative social scientific methods, although some use qualitative or mixed methods. Instead, they read texts closely with particular attention to the political context and to what practical implications for our shared world are contained in the work. We place political claims and activities in "political traditions" which, although historically and culturally specific, speak through the interconnections of ideas, history, and scholarship beyond their own particular political moment and place (Leopold \& Stears, 2008). We are also critical readers of texts, in part examining them for underlying ideological assumptions. Political theorists, albeit in very different ways and amid core disagreements about the relationship of ideas to history, draw on interpretations of thinkers from the past to attempt to illuminate problems today. Drawing on our sub-discipline, evidence of student learning can be read in several ways, including as a new set of commentaries on the primary texts and the political traditions they represent. They can also be interpreted as a political practice itself: interpreting texts about politics develops political consciousness. I read the sets of essays carefully, marking in color 
several thematic resonances, and then examined the way students approached the text as political actors, which led me to a theory of political judgment.

\section{Theme one: Developing an engaged voice}

In the first (pre-course) set of essays, students used hesitant or passive language. These responses were characterized by phrases like "I feel" and "I think" and cautious qualifications such as "perhaps" and "It could be that." In the beginning of the course, students were also more likely to use passive voice which, while not always identical to passivity, effaces their own agency. It may also reflect a social scientific approach to data in which the researcher is encouraged to take a neutral stance, and avoid "I" statements in hopes of assuring neutrality that they may have learned in other political science courses, but is challenged by political theory's interpretative methods. For example, in the 2014 course, one student wrote:

It may be that this chapter shows how the truth of independence for americans [sic] is the most important aspect according to the author. Equality is the most important aspect and I think that we can see here why. Equality can be linked to the importance of civil rights in our country and that may be reflected by this author.

Notice how the student uses words like "may," "can," and "according to the author," which produce a sense of distance between the student and the text. Although they make the creative link to the important example of civil rights, they do not follow this link to ask questions about what it could be or mean. This response suggests the student is not a participant in the political world they discuss.

In their second essays, students used active voices and engaged with other authors. They referenced the authors' names much more frequently (nearly twice as often), often as the subject of a sentence. When they used "I," which was less often, they were more likely to use it in phrases like "I argue" or, when still using "I think" or similarly tentative phrases, in relation to the higher-order questions. For example, this student's 2005 end-of-course essay includes the following:

In this passage, Tocqueville argues that Americans are unphilosophical, in a sense, although he also suggests they are very philosophical. This contradiction is not a mistake, but rather a distinction between being "a follower of Descartes" as in a reader and as in his ideas. I get the idea that Tocqueville is trying to say something very hard to say, or perhaps even mean. He seems to think that Americans are not very smart, because they don't read philosophy.

In this quote, the student engages with a thinker as another voice, clarifying where their idea ends and Tocqueville's begins. They comment directly— "this is not a mistake" — which implies authority, even playfulness. This is an "expert move" in much academic discourse but particularly in interpretative branches of the humanities where the text is the data (Graff \& Birkenstein, 2010). This student also digs into a moment of difficulty in the text: the seeming contradiction between different things implied about philosophy. Students in this second set of responses were frequently curious about some of the confusing or contradictory passages. While "I get the idea" may not be elegant phrasing, it succinctly reflects the work of inference in reading difficult texts: to get an idea and suss out what evidence there is for or against this interpretation. 


\section{Theme two: Conversations with political theory}

In the second writings, students were more apt to make connections to course concepts and the subfield of political theory. In the first essays, students tended to use the exact language from quotations or repeat answers from their lower-order answers in the higher-order categories. Yet the second essays featured more varied vocabulary, less repetition of the exact wording of the excerpts, and new class concepts such as race and criminal justice, libertarianism, and socialism. For example, one student tackled a discussion of "equality," a central theme in Tocqueville's Democracy in America, by applying it to the \#BlackLivesMatter movement. Tocqueville famously claims that America is the land of social equality, but this student asked: "can equality of conditions be a reality if police are racially biased?" This is a sophisticated question to put to Tocqueville who, while in other passages recognizes the racial problem in the U.S., often focused on individuals rather than systems. The student here recognized that equality of conditions depends not just on how we treat each other, but also on how our institutions work. Another student explored potential linkages between Paine and Ron Paul's Libertarian ideology, noting that "both see the connection between liberty and property." One wrote about socialism and equality in Tocqueville, wondering if Tocqueville's ideas only apply "to the wealthy." These students expressed nascent versions of professional concerns and approaches of political theory as they developed as readers. In fact, I can imagine a scholarly article written on the treatment of equality, criminal justice, and race in Tocqueville, Paine, and contemporary America.

\section{Theme three: Conversations with the world}

Third, students were also more likely, after the three new reading practices, to connect the passage to other American thinkers, ideologies, or historical events. To illustrate, one student at the beginning of the 2015 semester wrote, in a near paraphrase of Thomas Paine's Agrarian Justice that nonetheless lacks the sense of the original's meaning, which was to critique inequality and poverty:

"There are two types of property; natural and artificial. Natural Property is the subject of this short essay. But equal property is not possible." I take from this that the author is not a socialist, but for private property.

While the student has correctly connected the question of property to broader political discussions about socialism, lack of contextual knowledge caused the writer to miss that Paine argues in the text overall that some types of property must be equal, writing "poverty... is a thing created by that which is called civilized life." Compare the above confusion to when, in the post-semester essay, a student wrote:

Paine was writing to convince the American colonials to start a revolution. When he says every person born into civilization should have a life as good as it would have been if he had been born before civilization, I think he means that governments must do good things for the people to be legitimate. Similar to the Declaration of Independence, Paine argues for government to be for the people, by the people.

This passage is not perfectly clear, but it is stronger because it recognizes political discourse and sees Paine as part of the debate surrounding other early American thinkers. Indeed, the student appears to have inserted Lincoln's language from the Gettysburg Address ("for the people, by the people") backwards into the founding period! Still, this is a more convincing reading of the text than the first 
student offered, putting Paine in dialogue with other thinkers and speaking to a meaning in the text beyond the words, as here in the discussion of "good things" and political legitimacy.

\section{Missing theme: Where is the disciplinary reading?}

There was one interesting absence from all student work, despite an intensive focus on it in class: students did not explicitly reference disciplines or disciplinarity. Students did not mention political science, political theory, or philosophy (although mentioned in the passage) as a field of study. Although they made some initial movements towards interpreting like a political theorist, as noted above in theme two, they did not comment on this move as one done by disciplinary experts. While this is similar to the way that many political theorists act professionally, eschewing a detailed discussion of method in favor of performing in the text itself, I was still surprised at the absence of such metacognitive explicitness, given our work on "asking questions like a political theorist." Students may still place themselves in a different category from "experts" in the discipline. One did comment in a 2014 end-of-semester essay, "if we had a lecture on Paine, I would have a better sense of what he means." This desire for the "right" answer weighs heavily on readers and is an obstacle in a "grey area class" in which we advance persuasive and textually supported arguments_-perhaps even some wild arguments—rather than identify a "correct" interpretation. $^{5}$

While students are still developing the "deep reading" and metacognition I had hoped to encourage, these three themes do suggest that their relationship to their own reading changed. They wrote as more engaged thinkers who had the right to interpret and even criticize the text, linking it implicitly to discourse in political theory and to historical events or ideas. This is better and deeper reading because it requires that readers situate themselves in relation to the text, the field, and the political world, even if they are not doing so with explicit reference to disciplinary thinking.

\section{READING AS A PROCESS OF DEVELOPING REFLECTIVE JUDGMENT}

As students read better and more deeply, I wondered if this metacognitive change connected with Hannah Arendt's description of the development of political judgment, a metacognitive process of improved inner dialogue with self, text, and world. Reading my students' work through a lens of political judgment might help me understand what was happening as their reading habits changed. I also hoped Arendt might help me reconsider why my students did so little explicit commenting on disciplines.

Hannah Arendt, political theorist best known for her writing on evil, totalitarianism, and public spheres, explored political reflective judgment in the unfinished The Life of the Mind(1981), published after her sudden 1975 death. Political reflective judgments are needed when we encounter a new idea that does not fit into our existing schema, or our patterns of thinking. For Arendt, the pluralistic political world lacks these patterns, or predetermined rules, for action and thus we must determine how to judge and act by drawing on a shared "taste" for political life expressed in a special "common sense" gained through reflection. We imagine plural possible judgments about a political situation and reconsider our initial approaches by engaging with these ideas. Without reconsidering, we express only our initial impression. As one student wrote in the first essay in 2014, "I am a Republican and against giving all money to people who do not work," an unreflective judgment that neither references the text or what in the text suggested redistribution nor comments on this statement of political principle.

To reflect on the political world, for Arendt (2014), we must "go visiting," using imagination to consider and compare the possible opinions and viewpoints of others (p. 43). Visiting is not a movement of self-sacrifice, where we erase our own position, nor of universal impartiality, where we are removed from the world itself, but instead a situated engagement in imaginative inner dialogue. Placing 
this idea in the context of reading, a particular text provides a unique basis for our experience, but our response to it is also potentially generalizable beyond this particular text. For example, in a 2014 student end-of-semester essay:

Tocqueville says that "equality, pushed to its furthest extent, may be confounded with freedom" but he does not explain what he means by equality or freedom. I think of equality as being the same and being free as no one telling you what to do. But if he means something else by the words, because they are somehow related (I am not sure what cofounded [sic] means!) in this essay, or if everyone thinks they means something else, I am not sure what it means.

The student, in considering Tocqueville's position and also the possibility that meanings might be fluid or relative to different people, is beginning to consider the multiplicity of meanings and search for a perspective beyond themselves. This deepening helps develop an "enlarged mentality" or way of thinking that, for Arendt (2014)

is a question neither of empathy, as though I tried to be or to feel like somebody else, nor of counting noses and joining a majority, but of being and thinking in my own identity where actually I am not. (p. 241)

This engagement with the place where I am not, via Zerilli (2005), is how "we feel our freedom.” Our Arendtian judgment is enriched "though thinking in examples, in examples of persons dead or alive, and in examples of incidents, past or present" and thus expresses the work of deep reading (as quoted in Beiner, 2014, p. 29). I am connecting this development of an enlarged mentality to their reading practices, and not merely the passing of an entire semester, because the three central themes identified above all hover around perspective-taking and situating of the student in relation to ideas and the text.

I came to thinking about political judgment while reading the students' work because I found it otherwise hard to capture precisely why the later writing outshone the first. The end-of-course work is populated with varied perspectives and voices. Students mentioned other thinkers, including their fellow students, over ten times more frequently, speaking to an implied public audience, rather than a professor only. Students commented on more politically divisive topics; along with race, as mentioned above, they raised questions about gender and "marriage equality," economic inequality and "big banks," "massive student debt," the civil war, and "God given gun rights." While they were still developing nuanced practices of "going visiting," their reading practice became communal and lively. The second sets of essays could perhaps be collected in an edited volume, while the first would be a bit disjointed and stiff.

Deep reading cultivates this reflective capacity, as when one student asks in their second essay, on Paine:

my libertarian values fit with Paine in some areas, but are hostile to his ideas about distributing wealth to everyone. What would he say about Rand Paul and did his views change over time? I used to be more conservative, but I learned anarchism in social theory class and thought about the idea that poverty might be caused by government, as Paine writes.

The student thought about Paine in relation to their own beliefs, and their evolution, but also to other courses and political traditions. 
Students' improvement in the three areas - finding voice, making surprising connections, and linking theorists to broader families of political thinking - all resonate with the Arendtian idea of an "enlarged mentality" emerging from considering specific examples in dialogue with imagined positions of ourselves as others. The link between an enlarged mentality and reading is the need to consider the minds and habits of others, both as interlocutors and fellow readers. Indeed, deep reading and political judgment require, as with any metacognition, that students slightly distance themselves from their own positions and ways of thinking in order to evaluate them. Students also interpret texts inside and outside of class, a practice that provides material they can use as a way to "go visiting" ideas and perspectives of others.

Frequently, instructors use discussion to promote critical thinking. However, students might struggle to defend their ideas, or discussions might favor those who are already dominant, or well versed in disciplinary code. By first developing deep reading practices of sustained inner dialogue with another thinker or with historical exemplars and recursively coming back to their beliefs, students build the capacity for reflective judgment that Arendt (2005) hopes will kick in "when the chips are down" in the place of a universal moral system (p.39). She is speaking directly to the threat of totalitarianism and the need to cultivate "civil courage" to oppose it and see through ideology. A classroom becomes a community of readers who imaginatively play with the ideas of others and make their own ideas strange.

Democratic theories often focus on discussion and deliberation for developing political judgment, but one reason why reading may be more important than deliberation is that it offers a broader field of other positions than we encounter in even heterogeneous university settings, if reading includes voices of the marginalized. The more we incorporate anti-racist, feminist, and transnational voices into our classrooms and respond to disability studies, queer theory, and indigenous political philosophy, the richer our students' pluralistic world will be. This does not mean adopting a relativist multiculturalism that values all contributions equally, but instead places the texts in tension with each other so that students' reflections, including on their own beliefs, reverberate in a bigger world. An expanded canon is also important because disciplinary deep reading, like many other skills academically valued, has classed and racialized implications in contexts where educational opportunities are so shaped by these hierarchies. If students from a majority culture need more plural voices, marginalized students may need to hear their own subject-positions reflected to gain the confidence to enter into deliberative debates, which often reinscribe rather than combat inequalities.

\section{CONCLUSION}

I've argued that attending to the ways of reading, interpreting, and writing about texts in the undergraduate political theory classroom shows us that students can "go visiting" the perspectives of others when they read. It also may shed some light on how, despite the evidence of metacognitive development and self-reflection, their essays showed a striking lack of reflection on the disciplinary questions central to the approach I took to improving reading in political theory. In the movement of Arendtian judgment, the thinker is looking for exemplars, but not for categories. The idea is not to file new knowledge under existing schemas, but to creatively interweave it or play it off existing ideas and concepts. The disciplinary structure of academia, and its ordering of knowledge, strains to contain the always changing and pluralistic world of politics. Students first interpret texts in relation to this world, rather than the forms and discourse of the discipline.

It is always hard to choose between teaching content and teaching skills like reading that we hope our educational system would provide long before college. However, approaching undergraduate readers where they are, and valuing their interpretations as contributions to academic discourse in their 
own right, helps improve disciplinary reading habits. The disciplinary reading habits of political theory are part of the broader development of habits of political judgment that we desperately need.

\section{ACKNOWLEDGEMENTS}

This study received material and communal support from the University of Wisconsin-Green Bay Teaching Scholars Program, and a Teaching Enhancement Grant from the UWGB Instructional Development Council. I would also like to thank David Voelker, who read an early draft and provided feedback, encouragement, and pointed reminders about oxford commas. Thanks also to generous and insightful anonymous reviewers at Teaching \& Learning Inquiry, and to TLI editor Nancy Chick, whose deep reading and editing of my work has been invaluable.

Alison Kathryn Staudinger is Assistant Professor, Democracy, and Justice Studies at the University of Wisconsin, Green Bay.

\section{NOTES}

1. Hayles (2012) does not reject close reading, but suggests that "given the increase in digital reading, obvious sites for new kinds of reading techniques, pedagogical strategies, and initiatives are the interactions between digital and print literacies" (p. 59). One can imagine an exciting political theory project on cyborg reading that draws on Haraway's (1987) seminal work, as well as posthumanism, object-oriented ontology, and vital materialism.

2. Hearty thanks to an anonymous Teaching \& Learning Inquiry reviewer who suggested this great article as a parallel.

3. I use a singular "they/their" throughout as a pronoun, both to avoid gendered language and because not all people identify on the gender binary. While this is not yet standard practice in academic writing, the singular "they" was the American Dialect Society's 2016 word of the year and is included in many major newspaper style guides, including the Washington Post.

4. One place to start is Berlin (2000), whose titular question "Does Political Theory Still Exist?" from 1961 responded to in Wolin (1969); both in Botwinick and Connolly (2001). Strauss (1988) advocates for a practice of uncovering esoteric meaning in his expositions of the goals of political philosophy. Rawls (2008) treats this question as one about the relationship of philosophy to liberal democracy. Skinner (2002) offers an historical approach helpful for considering context and avoiding ahistoricism. And post-structuralist writers contribute interpretive practices such as deconstruction, genealogy, and hermeneutics that are indispensable. Feminist, Critical Race Theory, and Marxist scholars challenge the assumptions of all of the above thinkers.

5. UWGB is a problem-focused university where faculty teach and have a tenure-home in an interdisciplinary unit. Democracy and Justice Studies students seeks to understand the theories, historical practices, and concrete strategies in struggles to make the world a more democratic and just place, drawing on the methods of the social sciences and the humanities, with faculty from Women's and Gender Studies, History, Political Science, Sociology, and Economics.

6. In the future, I will conduct and study "read alouds" with a student co-investigator to learn more about how students' reading process works in relation to their metacognitive conceptions of academic disciplines. Please see Bloch-Schulman (2016) for a powerful example.

\section{REFERENCES}

Allington, R. L. (2011). What really matters for struggling readers: Designing research-based programs. Boston, MA: Pearson.

Arendt, H. (1970). Men in dark times. Boston, MA: Houghton Mifflin Harcourt. Arendt, H. (1981). The life of the mind. Boston, MA: Houghton Mifflin Harcourt

Arendt, H. (2014). Lectures on Kant's political philosophy. Chicago, IL: University of Chicago Press. Arendt, H. (2005). Responsibility and judgment. New York, NY: Schocken Books Incorporated. 
Ambrose, S. A., Bridges M., DiPietro, M., Lovett M. C., \& Norman, M. K. (2010). How learning works: Seven research-based principles for smart teaching. San Francisco, CA: Jossey-Bass.

Barton, D., Hamilton, M., \& Ivanič, R. (2000). Situated literacies: Reading and writing in context. New York, NY: Psychology Press.

Bean, J. C., Chappell, V., \& Gillam A. (2013). Reading rhetorically. New York, NY: Pearson.

Beiner, R. (2014). Interpretive essay: Hannah Arendt on judging. In Ronald Beiner (Ed.), Hannah Arendt, lectures on Kant's political philosophy (89-156). Chicago, IL: University of Chicago Press.

Berlin, I., \& Annan, N. (2000). The proper study of mankind: An anthology of essays. New York, NY: Farrar, Straus and Giroux.

Biesta, G. (2007). Why "what works" won't work: Evidence-based practice and the democratic deficit in educational research. Educational theory, 57(1), 1-22.

Bloch-Schulman, S. (2016). "A Critique of Methods in the Scholarship of Teaching and Learning in Philosophy." Teaching \& Learning Inquiry 4(1), 1-15.

Botwinick, A., \& Connolly, W. E. (Eds.). (2001). Democracy and vision: Sheldon Wolin and the vicissitudes of the political. Princeton, NJ: Princeton University Press.

Buehl, D. (2011). Developing readers in the academic disciplines. Newark, DE: International Reading Association.

Chevalier, T. M., Parrila, R., Ritchie, K. C., \& Deacon, S. H. (2015). The role of metacognitive reading strategies, metacognitive study and learning strategies, and behavioral study and learning strategies in predicting academic success in students with and without a history of reading difficulties. Journal of Learning Disabilities, 50(1), 34-48.

Chick, N. L., Haynie, A., \& Gurung, R. A. (2012). Exploring more signature pedagogies: Approaches to teaching disciplinary habits of mind. Chicago, IL: Stylus Publishing.

Hatteberg, S. J., \& Steffy, K. (2013). Increasing reading compliance of undergraduates an evaluation of compliance methods. Teaching Sociology, 41(4), 346-352.

Farr, R. C., \& Carey, R. F. (1986). Reading: What can be measured. Newark, DA: International Reading Assn.

Gamel, A. L. (2015). Help! My college students can't read: Teaching vital reading strategies in the content areas. Landham, MD: Rowman \& Littlefield.

Greene, S., \& Ackerman, J. M. (1995). Expanding the constructivist metaphor: A rhetorical perspective on literacy research and practice. Review of Educational Research 65(4), 383-420.

Geisler, C. (2013). Academic literacy and the nature of expertise: Reading, writing, and knowing in academic philosophy. London, UK: Routledge.

Graff, G., \& Birkenstein, C. (2010). They say, I say: The moves that matter in academic writing. New York, NY: W.W. Norton \& Company.

Greene, K. M., \& Maggs, J. L. (2015). Revisiting the time trade-off hypothesis: Work, organized activities, and academics during college. Journal of Youth and Adolescence, 44(8), 1623-1637.

Goodman, K. S., Flurkey, A. D., \& Xu, J. (2003). On the revolution of reading: The selected writings of Kenneth S. Goodman. Don Mills, ON: Pearson Education Canada.

Gurung, R. A., Chick, N. L., \& Haynie, A. (2009). Exploring signature pedagogies: Approaches to teaching disciplinary habits of mind. Chicago, IL: Stylus Publishing.

Haraway, D. (1987). A manifesto for cyborgs: Science, technology, and socialist feminism in the 1980s. Socialist Review, 80, 65-108.

Hayles, N. K. (2010). How we read: Close, hyper, machine. ADE Bulletin, 150(18), 62-79.

Hayles, N. K. (2012). How we think: Digital media and contemporary technogenesis. Chicago, IL: University of Chicago Press.

Hermida, J. (2009). The importance of teaching academic reading skills in first-year university courses. The International Journal of Research and Review, 3, 20-30.

Hutchings, P. (2000). Introduction. Opening Lines: Approaches to the Scholarship of Teaching and Learning. San Francisco: Jossey-Bass.

Keene, E., \& Zimmerman, S. (1997). Mosaic of thought; Teaching comprehension in a reader's workshop $2^{\text {nd }}$ Edition. Portsmouth, NH: Heinemann.

Krathwohl, D. R. (2002). A revision of Bloom's taxonomy: An overview. Theory into Practice, 41 (4), $212-218$. Leopold, D., \& Stears, M. (2008). Political theory: Methods and approaches. Oxford: Oxford University Press.

Martino, N. L., \& Hoffman, P. R. (2002). An investigation of reading and language abilities of college freshmen. Journal of Research in Reading, 25(3), 310-318. 
Meyer, J., \& Land, R. (2003). Threshold concepts and troublesome knowledge: Linkages to ways of thinking and practising within the disciplines. Edinburgh: University of Edinburgh.

Miller, D. (2003). Political philosophy: A very short introduction. Oxford: Oxford University Press.

Moje, E., Young, J., Readence, J., \& Moore, D. (2000). Commentary: Reinventing adolescent literacy for new times: Perennial and millennial issues. Journal of Adolescent \& Adult Literacy, 43(5), 400-410.

Monte-Sano, C. (2011) Beyond reading comprehension and summary: Learning to read and write in history by focusing on evidence, perspective, and interpretation. Curriculum Inquiry, 41(2), 212-249.

Middendorf, J., \& Pace, D. (2004). Decoding the disciplines: A model for helping students learn disciplinary ways of thinking. New Directions for Teaching and Learning, 98, 1-12.

Mulcahy-Ernt, P., \& Caverly, D. (2008) Strategic study reading. In R. F. Flippo \& D. C. Caverly, (Eds.), Handbook of college reading and study strategy research (177-198). New York, NY: Routledge.

Nist, S. L., \& Holschuh, J. P. (2005). Practical applications of the research on epistemological beliefs. Journal of College Reading and Learning, 35(2), 84-92.

Paine, T. (2003). Common sense, The rights of man and other essential writings of Thomas Paine. London: Penguin.

Pintrich, P. R. (2002). The role of metacognitive knowledge in learning, teaching, and assessing. Theory into practice, $41(4), 219-225$.

Pressley, M. (2000). What should comprehension instruction be the instruction of? In M. L. Kamil, P. B. Mosenthal, P. D. Pearson, \& R. Barr (Eds.), Handbook of reading research, (Vol. 3, pp. 545-563). Mahwah, NJ: Lawrence Erlbaum Associates.

Rawls, J. (2008). Lectures on the history of political philosophy. (S. Freeman, Ed.). Cambridge, MA: Belknap Press.

Reardon, Sean F. (2013.) The widening income achievement gap. Educational Leadership, 70(8), 10-16.

Reznitskaya, A., Kuo L., Clark, A., Miller, B., Jadallah M., Anderson R. C., \& Nguyen-Jahiel, K. (2009). Collaborative reasoning: A dialogic approach to group discussions. Cambridge Journal of Education, 39(1), 29-48.

Roberts, J. C., \& Roberts, K. A. (2008). Deep reading, cost/benefit, and the construction of meaning enhancing reading comprehension and deep learning in sociology courses. Teaching Sociology, 36(2), 125-140.

Ross, T., Kena, G., Rathbun, A., KewalRamani, A., Zhang, J., Kristapovich, P., \& Manning, E. (2012). Education: Gaps in Access and Persistence Study. Statistical Analysis Report. NCES 2012-046. National Center for Education Statistics.

Salvatori, M. R., \& Donahue, P. A. (2004). The Elements (and pleasures) of difficulty. New York, NY: Longman.

Schiefele, U., Schaffner, E., Möller, J., \& Wigfield, A. (2012). Dimensions of reading motivation and their relation to reading behavior and competence. Reading Research Quarterly, 47(4), 427-463.

Shanahan, C., Shanahan, T., \& Misischia, C. (2011). Analysis of expert readers in three disciplines history, mathematics, and chemistry. Journal of Literacy Research, 43(4), 393-429.

Shanahan, T., \& Shanahan, C. (2008). Teaching disciplinary literacy to adolescents: Rethinking content-area literacy. Harvard Educational Review, 78(1), 40-59.

Sharma, A., Van Hoof, B., \& Pursel, B. (2013). An assessment of reading compliance decisions among undergraduate students. Journal of the Scholarship of Teaching and Learning, 13(4), 103-125.

Sidler, M. (2005). Claiming research: Students as "citizen-experts" in WAC-oriented composition. The WAC Journal, 16, 49-60.

Sperling, R. A., Howard, B. C., Staley, R., \& DuBois, N. (2004). Metacognition and self-regulated learning constructs. Educational Research and Evaluation, 10(2), 117-139.

Strang, R., \& Rogers, C. (1965). How do students read a short story? The English Journal, 54(9), 819-829.

Skinner, Q. (2002). Visions of politics (Vol. 1). Cambridge: Cambridge University Press.

Smith, F. (1985). Reading without nonsense. New York, NY: Teachers College Press.

Smith, F. (2014). Landmarks in literacy: The selected works of Frank Smith. New York, NY: Routledge

Strauss, L. (1988). What is political philosophy? And other studies. Chicago, IL: University of Chicago Press.

Thompson, J. (2001). Writing a 'Live' Essay in Class.

Tocqueville, A. D. (2000). Democracy in America. (Harvey C. Mansfield \& Delba Winthrop, Trans.). Chicago, IL:

University of Chicago Press. (Original work published in 1835 and 1840)

Veeravagu, J.,V., Muthusamy, C., Marimuthu, R., \& Michael, A. S. (2010). Using Bloom's taxonomy to gauge students' reading comprehension performance. Canadian Social Science, 6(3), 205-212.

Waldron, J. (1991). Homelessness and the issue of freedom. UCLA Law Review, 39, 295-326.

Wineburg, S., Martin, D., \& Monte-Sano, C. (2014). Reading like a historian. New York, NY: Teachers College Press.

160 Staudinger, A. (2017). Reading deeply for disciplinary awareness and political judgment. Teaching \& Learning Inquiry, 5(1). http://dx.doi.org/10.20343/teachlearninqu.5.1.11 
Wolin, S. S. (1969). Political theory as a vocation. American Political Science Review, 63(04), 1062-1082. Wolf M., \& Barzillai, M. (2009). The importance of deep reading. Educational Leadership, 66(6), 32-37.

Zerilli, L. M. (2005). 'We feel our freedom:' Imagination and judgment in the thought of Hannah Arendt. Political Theory, 33(2), 158-188.

\footnotetext{
(c) (i) Copyright for the content of articles published in Teaching \& Learning Inquiry resides with the authors, and copyright for the publication layout resides with the journal. These copyright holders have agreed that this article should be available on open access under a Creative Commons Attribution License 4.0 International (https://creativecommons.org/licenses/by/4.0). The only constraint on reproduction and distribution, and the only role for copyright in this domain, should be to give authors control over the integrity of their work and the right to be properly acknowledged and cited, and to cite Teaching \& Learning Inquiry as the original place of publication. Readers are free to share these materials-as long as appropriate credit is given, a link to the license is provided, and any changes are indicated.
} 